\title{
Библиотеке и књижна продукција у Европи током 16. и 17. века
}

\author{
Гордана Стокић Симончић \\ Универзитет у Београду \\ Филолошки факултет - Катедра за библиотекарство и информатику, Београд \\ gordana.stokic.simoncic@gmail.com \\ Биљана М. Ђурашиновић \\ Универзитет Едуконс \\ Факултет за пројектни и иновациони менаџмент- Библиотека, Београд \\ biljana.djurasinovic@gmail.com
}

\begin{abstract}
Сажетак
У раду су представљене најважније промене у сфери објављивања и штампања „књига“, које су се десиле током 16. и 17. века. Издаваштво и штампарство приказани су кроз преглед делатности знаменитих појединаца и група у различитим европским земљама, а упоредо је дат преглед нових носилаца информација: летака, памфлета, брошура те периодичних публикација, попут календара, алманаха, новина и часописа.

Политичке, верске и културне промене, које су са собом донели јачање владарског апсолутизма, протестантизам, реформација, научна револуција и барок као уметнички правац, посматране су у овом раду из позиције историчара књиге, али и историчара библиотека. Пропадање манастирских збирки књига, које су током целог средњег века биле најзначајнији чувари писане баштине, развој краљевских колекција, универзитетских, специјалних и приватних библиотека богатих грађана, организација фондова, статус библиотекара и архитектура библиотека, представљени су тако да јасно сведоче о социјалној утемељености библиотечке делатности. Нарочито је истакнут значај текстова о урећењу библиотека који су се појавили у првој половини 17. века: они су доприносили ширењу знања о начину организације фондова, што је током следећих стотинак година довело до стварања савремених типова библиотека.
\end{abstract}

Кључне речи: Европа, 16. и 17. век, библиотекарство, библиотеке, организација, архитектура, издаваштво, штампарство, књига, периодичне публикације

\section{Увод}

Пошто се, на самом почетку 16. века, завршила епоха раних штампаних књига - инкунабула, а свој радни век окончао и најзнаменитији штампар на прелому векова - Алдо Мануцио (Aldo Pio Manuzio, 1449/1452-1516), корените друштвене промене (верске, политичке, научне) на тлу Европе довеле су до револуционарних промена у развоју књиге и библиотека. На немачком тлу покренут је процес реформације Католичке цркве, ${ }^{1}$ који је на дуге стазе променио верску слику Европе. Нако је 1555. године, на црквеном сабору у Аугсбургу, званично призната лутеранска, протестантска вероисповест, прогони и верски ратови смењивали

\footnotetext{
Покрет који је настао у оквиру Католичке цркве - реформација, иницирао је свештеник Мартин Лутер (Martin Luther, 1483 1546) тако што је, 1517. године, на врата дворске цркве у Витенбергу, поставио 95 теза о потреби коренитих промена. Једна од основних примедби односила се на праксу опроштајница у оквиру Цркве према којој се опрост грехова давао свакоме ко за то издвоји одређена средства, што је било у супротности са догмом коју је проповедала. - Aleksandar Stipčević, Povijest knjige (Zagreb: Izdavački zavod Matice hrvatske, 1985), 346.

Противреформација представља римокатоличку обнову осмишљену на сабору у Тренту (1545-1563). - Beatris Komelja, Španska inkvizicija (Beograd: Clio, 2003), 18
} 
су краткотрајне периоде мира све до краја Тридесетогодишњег рата (1618-1648). ${ }^{2}$ У огорченој борби између протестаната и католиказ писана реч коришћена је као моћно средство обавештавања и креирања јавног мњења, па је резултат овог верског сукоба постала и свест савременика о моћи штампе, односно пропаганде коју она шири. У том дугом периоду, лакоћа штампања и умножавања писаног текста утицала је и на промене у обиму и врсти библиотечких фондова, али и на промене у структури корисника библиотека.

Слику дотадашње Европе почела је од средине 16. века да мења и научна револуција - скуп открића и промена у науци, ${ }^{4}$ коју је својим деловањем започео Никола Коперник (Nicolaus Copernicus, 1473-1543). ${ }^{5}$ Његове виђење устројства свемира прихватио је Ђордано Бруно (Giordano Bruno, 1548-1600), а током 17. века истим проблемима бавио се Галилео Галилеј (Galileo Galilei, 1564-1642). ${ }^{6}$ Његова подршка Копернику изазвала је гнев учених филозофа и свештенства, јер су принципи планетарног кретања које је заступао угрожавали слику света засновану на античким ауторима, Светом писму и схоластичкој традицији. Индексна конгрегација, ${ }^{7}$ која је представљала орган Цркве за цензуру, осудила је 1616. године коперниканизам, а Инквизиција ${ }^{8}$ Галилеја на доживотни затвор. Практичну примену појединих Галилејевих теоријских сазнања спровео је Блез Паскал (Blaise Pascal, 1623-1662), док врхунац научне

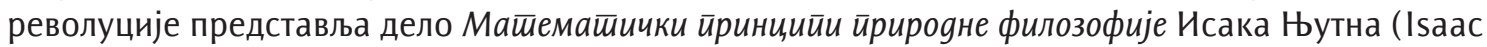
Newton, 1642-1727) из 1687. године.

Захваљујући раду Франсиса Бекона (Francis Bacon, 1561-1626) и његовом делу Нови орїанон науке (1620), током 17. века успостављени су и методи научног истраживања. Он је заступао индуктивни метод у науци и један је од оснивача емпиријске традиције у модерној филозофији. Супротно њему, Рене Декарт (René Descartes, 1596-1650), који се сматра оснивачем модерне филозофије, заступао је дедуктивни (рационални) метод у наукама, што је објаснио у свом делу Расирава о мешеоли (1637). ${ }^{9}$

Промене у схватању друштвене улоге религије и науке довеле су у различитим земљама Европе до стварања библиотека и библиотечке праксе у складу са захтевима новог времена, односно до (ре)организовања ових институција у складу са цивилизацијским достигнућима 16. и 17. века. То је посебно видљиво кроз пропадање фондова манастирских библиотека, нарочито у областима где протестантизам ${ }^{10}$ постаје доминантна религија. У издаваштву долази до појаве нових типова публикација попут летка, памфлета, годишњака и других, а одређен је и сталан начин попуњавања колекција доношењем прописа о обавезном примерку.

\footnotetext{
2 Детаљније видети на: Encyclopaedia Britannica s.v. "Thirty Years' War, european history", preuzeto 8. 1. 2019, https://www.britannica.com/event/Thirty-Years-War.

3 Marvin Peri, Intelektualna istorija Evrope (Beograd: Clio, 2002), 84

${ }^{4}$ Ibid., 89

5 Дело О кружењу небеских орбита из 1543. године пружило је ново виђење изгледа земље и довело у питање дотадашња знања о овом проблему. - Peri, Intelektualna istorija Evrope.

${ }^{6}$ Публикација Дијалої који се оgноси на gва їлавна сисиема свейа-Пйолемејев и Койерников из 1632. године. - Peri, Intelektualna istorija Evrope.

${ }^{7}$ Посебна црквена комисија која се бринула за издавање и попуњавање пописа забрањених књига, основана 1571. године. Први општи попис забрањених књига - Index librorum prohibitorum израдила је римска инквизиција 1557. (проширено издање штампано је 1559. године) и називао се Римски инgекс. Пре њега су у појединим европским земљама израђивани пописи забрањених књига, а прва је била дело енглеског краља Хенрија VIII, штампана 1526. године. - Детаљније видети у: Stipčević, Povijest knjige, 376-380.

8 Први инквизиторски суд успостављен је 1220. године на захтев Фридриха II Хоенштауфена (владао као краљ Сицилије од 1197. до 1250; швапски војвода од 1228. до 1235; немачки краљ од 1212. до 1250. и цар Светог Римског царства од 1220. до 1250). Током модерног доба (од 15. до 19. века) била је блиско повезана са световном влашћу. - О Инквизицији детаљније видети у: Komelja, Španska inkvizicija.

${ }_{9}$ Peri, Intelektualna istorija Evrope, 95-124; 147-162.

10 Током трајања сељачког рата 1524. и 1525, у појединим немачким областима уништене су многе манастирске и библиотеке велепоседника. Поред тога, у току реформације, библиотечки фондови, првенствено они настали у оквиру католичких црквених редова (фрањевци, доминиканци и други), постају део новостворених библиотека, нарочито у оквиру универзитетских центара, што је утицало и на развој науке. - Stipčević, Povijest knjige.
} 


\section{„Књига“, штампарство и издаваштво током 16. и 17. века}

Европа је у 16. и 17. веку доживела процват штампарства и издаваштва. „Према најпоузданијим проценама, пре Гутенберга број рукописних књига у Европи се кретао у хиљадама. У то време у Европи је вероватно било мање од сто милиона становника, а већина њих била је неписмена. Године 1500. у оптицају је вероватно било око десет милиона штампаних књига (мада има стручњака који би ти цифру удвостручили), поред постојећег фонда рукописних књига, који се такође непрекидно увећавао“. ${ }^{11}$ Истовремено, било је писмено око 5\% житеља Европе, па штампани текст није више намењен само најбогатијима и малом броју образованих, него је у грађанском становништву добио ширу читалачку публику. Књига постаје доступнија и због тога што више не доминира латински, него се пише/штампа на националним језицима, па и зато што више није нужно скупа, раскошна и тешко преносива. Напротив, штампани текст постаје све више медиј масовне комуникације, јер знатно увећан број оних који умеју да читају омогућава бржи пренос штампане информације аналфабетама, а ове их усменим путем преносе даље. Штампана публикација почиње да служи и као извор информација о актуелним догађајима, помагало у процесу образовања, као средство разоноде, али и као пропагандно оружје у идеолошким и верским сукобима. ${ }^{12}$ Штампарство и издаваштво постају раширени, а као занат врло уносни и тржишно оријентисани. То ће условити да се објављује велики број наслова, да они буду врло разнолике садржине, духовног и световног карактера, али и да носиоци графичких записа постану врло различити: књиге, брошуре, алманаси, календари, плакати, леци, новине, часописи, научна издања, картографски материјал.

Како се дубље улази у 16. век, штампане књиге су све ређе верске, а све чешће световне садржине (поучне, историјске и забавне), са тиражима који су и за данашње појмове велики. На пример, Похвалу луgосии Еразма Ротердамског (1466-1536) штампао је у Базелу 1515. године штампар Јохан Фробен у 1800 примерака, а у року од месец дана било је продато готово цело прво издање. За Еразмовог живота уследило је још 27 издања ове књиге. ${ }^{13}$ Још изразитији је пример Мелкиора Лотера (Melchior Lotter, ? - око 1542), штампара који је 1519. отворио штампарију у Виртенбергу, са намером да објављује Лутерова дела. Он је, 1520. године, Лутеров спис Хришћанском йлемсйву немачкої нароgа штампао у 4000 примерака, а затим у кратком року објавио још 15 издања овог текста. И наредних година објављивао је Лутерова дела, међу којима и његов превод Нової завешиа на немачки (1522), чиме се веома обогатио. ${ }^{14}$

У штампаној књизи се, током 16. века, уобичајио низ карактеристика за које рукописна није знала: насловна страница са импресумом тј. именом аутора, насловом, местом издања, именом штампара и годином штампања, као и знак штампара, односно типографска марка. Књиге добијају пагинацију, страницу која приказује садржај публикације и колофон, али су првобитно углавном биле без корица; са њиховом појавом, на крају 16. века, почеће да се јавља $e x$ libris као ознака власништва над публикацијом - свој грб или другу врсту знака власник књиге је лепио на унутрашњу страну корица. ${ }^{15}$ Најзад, фиксирани текст омогућио је и појаву индекса, за лакше претраживање штампаних књига. ${ }^{16}$ Барокна уметност украшавања публикација, која се током друге половине 16. века развила у Италији, довела је до непотребне раскоши у илустровању књига, што је било изражено и током 17. века. Објекат престижа постаје и повез,

\footnotetext{
11 Danijel Dž. Borstin, Svet otkrića: Pripovest o čovekovoj potrazi za spoznajom sveta i samog sebe (Beograd: Geopoetika, 2003 ), 541

12 Milan Pelc, Pismo - knjiga - slika: Uvod u povijest informacijske kulture (Zagreb: Golden marketing, 2002), 141-142.

13 Aleksandar Stipčević, Povijest knjige: drugo, prošireno i dopunjeno izdanje (Zagreb: Matica hrvatska, 2006), 390.

14 Isto, 454.

15 Pelc, Pismo - knjiga - slika, 143-144.

16 Borstin, Svet otkrića, 539
} 
који је у појединим земљама имао значајне представнике (нпр. породица Ђунта у Италији, Жан Гролијер у Француској и други). ${ }^{17}$

Поред наслова из лепе књижевности, посебно место заузеле су публикације из природних наука, историје и права. Повећање књижне продукције довело је и до појаве јефтинијих издања која су била намењена свим слојевима становништва. Међу њима, најзначајнији су били календари и алманаси, који су се штампали у одређеним временским размацима и то најчешће једанпут у току године. ${ }^{18}$ Ове књиге, намењене претежно народу, разликовале су се по томе што је у календарима примаран био календар, па затим разна практична упутства о томе шта треба радити и у које доба године, народна веровања, пословице, изреке, различита астролошка тумачења и слично, док су алманаси доносили и књижевне и научне текстове прилагођене пуку. Касније, у доба просветитељства, алманаси су постали зборници разнородних штива која имају васпитну функцију популаризатора научних достигнућа, уметничких и политичких програма. Њихова популарност била је огромна, у прилог чему Стипчевић наводи податак да је само у Паризу, између 1600. и 1895. године, пописано 3633 такве едиције. ${ }^{19}$

Са почетком Реформације, у широку употребу ушле су кратке форме попут летка и памфлета. Њима су се нештедимице руглу извргавали верски противници и то у речи и слици. Илустрација која је рађена у дрворезној техници, као карикатура или увредљива сличица, са кратким пропратним текстом, постала је убојито оружје протестаната у борби против католика, најпре и понајвише у Немачкој, али и широм Европе. Објављено их је на хиљаде. Уз њих, евидентирано је и постојање преко 10.000 разних брошура - кратких публикација у којима се објашњавају или образлажу поједина актуелна политичка или верска дешавања. ${ }^{20}$

Као нова средства писане комуникације појављују се, такође, новине и часописи. Извесна врста рукописних новина постојала је још у средњем веку, али је појаву периодичних публикација, тј. медија који ће брзо преносити кратке вести о узбудљивим догађајима, омогућила појава штампе. Књижице поводом значајних догађаја, пригодног карактера, појављују се почетком 16. века у Немачкој, али оне још немају одређену периодичност и тематску разноврсност која одликује новине и часописе. Но, на самом крају 16. века појавиле су се прве публикације са таквим карактеристикама: током 1597. године, независно једна од друге, излазиле су у Аугсбургу (Немачка) и Роршаху (Швајцарска), месечне публикације са разнородном садржином. Друга деценија 17. века ће, међутим, забележити појаву петнаестодневних или месечних новина у низу европских градова. ${ }^{21}$

Прве дневне новине у Европи почеле су да се објављују 1660. године, а издавао их је у Лајпцигу штампар Тимотеус Рич (Timotheus Ritzsch, 1614-1678), али оне нису биле дугог века. Тек почетком 18. столећа појавиће се неколико наслова у Енглеској због којих је она постала прва земља у Европи која има дневна гласила.

Французи, који су прве дневне новине Париски журнал (Journal de Paris) добили тек 1777. године, носе заслуге за покретање најранијих часописа. Премда се први часопис појавио у Паризу 1633. (Bureau d'Adresses), најзначајнијим се сматра Научни журнал (Le Journal des Scavants), чији је први број објављен почетком 1665. године. У наредних неколико година учена друштва покренула су научне часописе и у Лондону, Риму и Лајпцигу. Французи ће, међутим, остати упамћени и као покретачи првог књижевно-забавног часописа, Le Mercure galant, који је почео да излази у Паризу 1672. године. ${ }^{22}$

\footnotetext{
17 Stipčević, Povijest knjige, 394-407; 412-414

18 Isto, 353-354; 360-362.

19 Stipčević, Povijest knjige: drugo, prošireno i dopunjeno izdanje, 471-472.

${ }^{20}$ Stipčević, Povijest knjige: drugo, prošireno i dopunjeno izdanje, 453-454; Pelc, Pismo - knjiga - slika, 146-147.

${ }^{21}$ Stipčević, Povijest knjige: drugo, prošireno i dopunjeno izdanje, 475-476.

22 Isto, 477-478
} 
У циљу бољег информисања о новоштампаним издањима и ширења знања у свим областима, појављују се опште и специјалне библиографије и енциклопедије. Код израде библиографија велику помоћ пружали су каталози са сајмова књига, од којих су најпознатији одржавани у Франкфурту и Лајпцигу. ${ }^{23}$

Најзад, треба нагласити и то да су се послови објављивања временом усложњавали, а сам занат - штампарски, како се назива у првим деценијама након Гутенберговог изума - почео је да се модификује. Штампар, издавач и књижар су првобитно били једно. Тако је највећи немачки штампар с краја 15. и почетка 16. века, Антон Кобергер (1440?-1513) отворио своју штампарију у Нирнбергу 1470. године, ${ }^{24}$ а упоредо је имао и радионицу за производњу папира, као и продајне испоставе у Антверпену, Паризу, Лиону, Бечу, Кракову, Будиму и Милану (од деведесетих година 15. века). Но, од почетка 16. века лагано се у засебне делатности издвајају издаваштво, штампарство и књижарство, с тиме што најугледнија међу њима постаје издавачка делатност. Издавачи све чешће преузимају одговорност за наручивање књига од аутора и преводилаца, за осмишљавање издавачке политике и за коректност издања. Они ангажују илустраторе, књиговесце, дистрибутере, а штампар све више постаје сервис издавача. ${ }^{25}$

Док су, током првих деценија штампарства, престоницама овог заната сматране Немачка и Италија, током наредна два века примат је преузела Холандија - најлибералнија земља Европе у то доба.

Кристоф Плантин (Christophe Plantin, 1520-1589) био је најславнији штампар друге половине 16. века. Француз пореклом, он је од 1549. радио у Антверпену, једном од највећих и најбогатијих градова Европе тога доба. ${ }^{26}$ У свом штампарско-издавачком предузећу запошљавао је преко стотину сарадника, а током 34 године деловања објавио је око 2000 публикација, односно у просеку 59 књига годишње. Своју штампарију оставио је Јану Моретусу (Joannes Moretus, 1543-1610), чији су се наследници бавили овим занатом све до 1876. године. Однос између штампаних публикација Плантина и Моретуса осликава и разноликост у ширењу идеја у Европи 16. и 17. века. Књиге штампара Кристофа Плантина углавном су подржавале противреформацију, док су оне штампане у оквиру породице Моретус биле наклоњеније реформацији. Плантинова издања стекла су изузетан углед због свога квалитета. Остало је забележено да је Плантин у аули лајденског универзитета излагао пробне отиске дела која је припремао за штампу и нудио награду свакоме ко нађе грешку. ${ }^{27}$ Плантиново најзначајније дело, Biblia Polyglotta, штампана је на пет језика, у осам свезака великог формата у периоду од 1569. до 1573. године. ${ }^{28}$

Друга значајна холандска штампарска породица била је Елзевир (Elzevir). Родоначелник породице, Лодовик Елзевир отворио је штампарију у Лајдену 1583. године, да би током 17. века она доживела врхунац свога успеха. Посао су разгранали Лодовикови синови: двојица су наследила очев посао у Лајдену, а друга двојица имала су сопствене штампарије у Хагу и Утрехту. Фирма је имала представништво у Лондону и Паризу, а у Франкфурту посебно уређено складиште из кога је дистрибуирала књиге широм Европе. Последњи члан породице, Абрахам Други, умро је 1712. и са њиме је угашено и ово предузеће.

\footnotetext{
23 Stipčević, Povijest knjige, 370-374; 390-394

24 Око 1480. године у Кобергеровој штампарији радило је око 100 словослагача, штампара, коректора, словорезача, илуминатора, књиговезаца, а некада су радиле и 24 штампарске пресе истовремено. Кобергер је за живота објавио преко 200 наслова, али су његови наследници већ око 1520. довели ово предузеће до банкротства. - Pelc, Pismo - knjiga - slika, 128-129.

25 Stipčević, Povijest knjige: drugo, prošireno i dopunjeno izdanje, 422-424.

26 Хелмут Г. Кенигсбергер, Џери К. Боулер и Џери Л. Моуз, Евройа у шеснаесйом веку (Београд: Clio, 2002$), 130$.

27 Pelc, Pismo - knjiga - slika, 142

28 Данас се у Антверпену налази музеј посвећен овим породицама у којем се може сагледати део штампарске делатности током 16. и 17. века. - Детаљније видети на: Museum Plantin Moretus, preuzeto 17. 10. 2021, https://www.museumplantinmoretus.be/ en.
} 
У штампаријама Елзевирових штампано је преко 5000 наслова књига, квалитетних, са поузданим текстом и при томе релативно јефтиних. ${ }^{29}$ Многе од наслова објавили су за потребе универзитета у Лајдену, а свака књига од 500 страница коштала је 1 гулден. Посебно је била популарна серија њихових књига о земљама и покрајинама света - Republiken, која је у 35 свезака објављена између 1625. и 1649. године. ${ }^{30}$

Поред Холандије, развијену штампарску делатност имала је и Шпанија, где ће до средине 16. века књиге задржати изглед инкунабуле. На развој штампарства утицало је и оснивање удружења штампара 1557, након чега нико ко није био његов члан није могао да се бави овим послом. ${ }^{31}$ Француска је, током 16. и 17. века, била позната по штампарији Естијен (Estienne). Француски краљ Франсоа I (владао од 1515. до 1547) 1539. је именовао Анрија Естијена, једног од чланова ове породице, за краљевског штампара. Упркос томе, може се закључити да су у Француској слобода штампе и издаваштво били у опадању, јер је од друге половине 16. века јачала цензура због чега се смањивао број штампарија, као и број градова у којима су се објављивале књиге. ${ }^{32}$

У оквиру Немачке, штампарска делатност се, поред старих центара попут Мајнца, Келна и Нирнберга, под утицајем реформације развијала и у Виртенбергу, док је Италија била позната по раду породице Ђунта, односно Ђунти (Giunta, Giunti) и штампарији у оквиру Ватикана, која је била посебно значајна у борби против протестантске штампе, којој је требало да допринесе и стварање индекса забрањених књига. Последица деловања Инквизиције и постојања Индекса била су и измишљена места штампања публикација и имена издавача, што је нарочито изражено од 16. века. ${ }^{33}$

Утицај немачких штампара био је видљив и у Пољској, где су прве публикације на латинском језику штампане већ крајем 15, да би током 16. века у Кракову радило 12 штампарија, а у следећем веку штампан је и Индекс забрањених књига. ${ }^{34}$ Од манастирских штампарија најстарија се налазила у Лавову, док је највећа била у Кијевско-печерској лаври (основана 1616). ${ }^{35}$

Разграната штампарска продукција утицала је и на структуру и делатност чувара писаног наслеђа - библиотека, које су, упркос захтевима новог времена сачувале своје основне функције - чување и обраду грађе, али су, поред тога, постале отвореније за приступ својим фондовима, што је утицало и на њихов значај.

\section{Библиотеке - организација делатности и уређење простора}

За разлику од Италије, која ће све до друге половине 19. века остати подељена на кнежевине којима владају обласни господари, у претежном делу Европе јачала је, током 16. и 17. века, световна власт оличена у личности краљева. Били католици или протестанти, они су утемељивали модерне централизоване националне државе, а своју моћ доказивали су и оснивањем библиотека. Поред њих, у Европи експанзију доживљавају универзитетске библиотеке, али и приватне библиотеке образованих појединаца.

Италија, у којој су у периоду ренесансе настале најраскошније библиотеке Европе, традицију њиховог отварања наставила је и током 16. и 17. века. Библиотеке овог периода разликовале

\footnotetext{
29 До данашњег дана наслови елзевира (публикације које су издавали чланови породице Елзевир), заједно са алдинама и инкунабулама, представљају највеће богатство за сваког библиофила.

30 Pelc, Pismo - knjiga - slika, 155.

31 Stipčević, Povijest knjige, 332-338

32 Isto, 330.

33 Isto, 322-330; 387

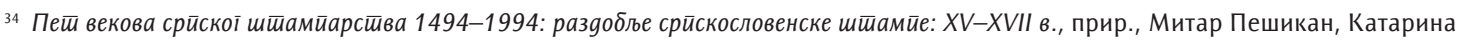
Мано-Зиси и Миљко Ковачевић (Београд: Српска академија наука и уметности; Народна библиотека Србије; Нови Сад: Матица српска, 1994), 10-11.

35 Исто, 18.
} 
су се од ранијих по томе што су њихови оснивачи били из редова црквених власти и образовани појединци, а не богате породице попут Медичија (Medici), Д’Есте (D’Este), Гонзага (Gonzaga) и других.

Библиотека Амброзијана основана је 1609. године, залагањем миланског надбискупа Федерика Боромеа (Federico Borromeo, 1564-1631). Назив је добила по заштитнику Милана светом Амброзију, а смештена је у зграду посебно изграђену за њу, која се налази у близини Катедрале. Библиотека Анђелика је установљена заслугом припадника католичког реда августинаца Анђела Роте (Angelo Rotta, 1545-1620), 1614. године. Амброзијана у Милану и Анђелика у Риму једине су које су дозвољавале приступ особама које се нису бавиле научним радом и представљају прототип „јавне“ библиотеке у 17. веку, ${ }^{36}$ при чему се појам јавности односио на начин приступа фондовима, а не на њихово финансирање, као у случају нама савремених јавних библиотека.

Припадници католичких црквених редова основали су још две библиотеке: Казанатензе и Алесандрину. Прва је створена радом кардинала Ђиролама Казанатеа (Girolamo Casanate, 1620-1700), а за јавност је отворена 1701. године. Основу фонда чинила је кардиналова приватна библиотека од 25.000 примерака публикација. Друга је отпочела делатност заслугом папе Александра VII (Alessandro VII, 1599-1667) средином 17. века и њен фонд је данас део Универзитета у Риму (Biblioteca Universitaria Alessandrina). ${ }^{37}$

Током 16. и 17. века, свој развој наставила је и једна од највећих црквених библиотека на свету - Ватиканска (Biblioteca Apostolica Vaticana), која између 1577. и 1579, заслугом Доменика Фонтане (Domenico Fontana, 1543-1607), добија нову зграду, што је омогућило бољи смештај и организацију збирки. Током 16. века раздвојени су архив и књижни фонд, а Ватиканска штампарија премештена је у посебну зграду поред Библиотеке. Значајније повећање колекција уследило је током 17. века, када су оне увећане за кодексе из манастира Бобио и Хајделбершке библиотеке - Палатине која је, између осталог, обухватала и публикације катедрале у Мајнцу и неколико других сакралних установа. До времена столовања папе Урбана VIII (1623-1644), колекције Ватиканске библиотеке обухватале су 6000 латинских и 1500 рукописа на грчком језику. ${ }^{38}$

На територији Италије, током 16. и 17. века, велики углед имале су приватне колекције књига. Њихов изглед у пракси је могуће реконструисати на основу неколико појединачних примера, међу којима се издвајају библиотека Одисеја Алдровандија (Ulisse Aldrovandi, 1522-1605) и библиотека Ђан Винћенца Пинелија (Gian Vincenzo Pinelli, 1535-1601).

Одисеј Алдрованди, као професор болоњског универзитета, поседовао је вредну библиотеку која се може реконструисати кроз његове белешке из 1599. и кратак инвентар, чији аутор није познат, из 1610. године. Књиге су биле сложене у ормарима на нумерисаним полицама, али не у континуитету, од I до 303. За своју колекцију професор је предложио и класификациони систем подељен на 30 области, који је касније смањен на шест, а обухватао је: теологију, филозофију, медицину, математику, поезију и историју. Упркос овом начину слагања, публикације су биле организоване према формату. ${ }^{39}$ Библиотеку је завештао граду Болоњи, уз услов да се чува у просторијама које је требало да служе искључиво чувању фонда, што је и урађено

\footnotetext{
${ }^{36}$ Erin M. Grant, "Two views on the Increasing importance of library access in the Seventeenth Century: Gabriel Naude and Claude Clement", Georgia Library Quarterly Vol. 50, Issue 4, Article 10 (Fall 2013): 3, preuzeto 15. 11. 2018, http://digitalcommons. kennesaw/glq/vol50/iss4/10.

37 Stipčević, Povijest knjige, 427-428.

38 Encyclopedia of Library History, ed. Wayne A. Wiegand and Donald Davis (New York: Garland Publishing, 1994$), 654$.

${ }^{39}$ Caroline Duroselle-Melish and David A. Lines, "The Library of Ulisse Aldrovandi (+1605): Acquiring and Organizing Books in Sixteenth Century Bologna", The Library $7^{\text {th }}$ series, Vol. 16, No. 2 (June 2015): 135; 138-139, preuzeto 16. 11. 2017, https:// s3.amazonaws.com/academia.edu.documents/38146759/Library-2015-Duroselle-Melish-Lines-final.pdf?AWSAccessKeyld=AKIAIWOWYYGZ2Y53UL3A\&Expires=1510856027\&Signature=C\%2BB\%2F5cPXTVYlwIQKXSvshsLeYDo\%3D\&response-content-disposition=inline\%3B\%20filename\%3DThe_Library_of_Ulisse_Aldrovandi_1605_Ac.pdf.
} 
1617. године. Сплетом различитих околности (првенствено због жеља појединаца да поседују публикације из Алдровандијеве колекције), збирка није у потпуности сачувана онако како је одредио дародавац. Током времена, фонд се увећавао (најчешће поклонима) и данас је део Универзитетске библиотеке Болоње. ${ }^{40}$

Заљубљеник у ботанику, библиофил и ерудита Ђан Винћенцо Пинели, ${ }^{41}$ поседовао је библиотеку од око 9000 штампаних публикација и неколико хиљада рукописа. Налазила се у Падови и била је доступна образованим слојевима друштва, а у оквиру ње су се организовали и разговори на различите теме. Наиме, њен творац је имао идеју да она не буде само чувар достигнућа у одређеној области, већ да доприноси проширењу и увећању знања сваког њеног члана. Упркос Пинелијевој жељи, колекција није у потпуности сачувана, а део фонда завршио је и у миланској библиотеци Амброзијана. ${ }^{42}$ Током живота Ђан Винћенца Пинелија, публикације су чуване у 21 ормару, који је био обележен једним словом алфабета (А-Х). Биле су подељене по језицима, са потподелама на ауторе и предмете. Слова су лепљена на ормаре, а бројеви на полице. Свака књига била је забележена у алфабетском индексу. ${ }^{43}$

Француска је током 16. и 17. века била културни центар Европе. ${ }^{44}$ Краљевску колекцију књига, која се готово два века установљавала, ревитализовао је краљ Франсоа Први 1518. године. Он је децембра 1537. издао декрет по којем библиотека у краљевском дворцу Блоа мора да добије бесплатно по два примерка сваке књиге која се штампа у земљи. Тако је установљен најстарији обавезни примерак у Европи. „(...) Године 1544, под управом библиотекара краља Франсоа I, Гијома Бидеа, ${ }^{45}$ садржај фондова библиотека у дворцима Блоа и Фонтенбло је спојен, па је тиме означено институционално стварање Краљевске библиотеке. ${ }^{\prime 46}$ Док је у првој половини 17. века прилив штампаних књига у библиотеку слаб јер је обавезни примерак лоше функционисао, у другој половини века фондови библиотеке су нагло порасли, али су обогаћени и различитим врстама грађе. Заслуге за то припадају понајвише премијеру Жан-Батисту Колберу (Jean Baptiste Colbert, 1619-1683), који надгледа рад библиотеке и стара се о реализацији обавезног примерка, куповином и поклонима додатно обогаћује фонд те јој прикључује богате збирке гравира, цртежа и медаља. Од почетка 17. века краљевска библиотека је потпуно сређена, има свој алфабетски и стручни каталог; од 1692. два пута недељно отворена је за јавност. Према једном каталогу из 1697. она, осим других врста грађе, поседује 55.107 штампаних томова. ${ }^{47}$

У Француској је током 16. и 17. века класа образованих људи сакупила публикације и створила низ знаменитих библиотека. ${ }^{48}$ Таква је била она министра Жила Мазарена (Jules Mazarin, 1602-1661), која је за јавност отворена 1644. године, а где је библиотекар био Габријел Ноде (Gabriel Naude, 1600-1653), први значајни теоретичар модерне организације

40 Ibid.: 140-142.

41 О животу и раду детаљније видети у: Angela Nuovo, Gian Vincenzo Pinelli's collection of catalogues of private libraries in sixteenth century Europe, 129-144, preuzeto 20. 10. 2018, https://www.academia.edu/3868798/ Gian_Vincenzo_Pinellis_collection_of_catalogues_of_private_libraries_in_sixteenth-century_Europe.

${ }^{42}$ Angela Nuovo, The Creation and Dispersal of the Library of Gian Vincenzo Pinelli, 39-47, preuzeto 19. 10. 2018, http://www.academia.edu/3870620/The_Creation_and_Dispersal_of_the_Library_of_Gian_Vincenzo_Pinelli.

43 Ibid., 49.

${ }^{44}$ Stipčević, Povijest knjige: drugo, prošireno i dopunjeno izdanje, 546-547

45 Детаљније видети у: Encyclopaedia Britannica s.v. "Guillaume Bude, french scholar", preuzeto 8. 1. 2019, https://www.britannica. com/biography/Guillaume-Bude.

${ }^{46}$ Bette W. Oliver, "The Bibliotheque nationale from 1792 to 1794: Becoming a National Institution during the French Revolution", Libraries \& Cultural Record Vol. 42, No. 1 (2007): 48, preuzeto 17. 5. 2017, https://www.jstor.org/ stable/25549380?seq=1\#page_scan_tab_contents.

47 Весна Ињац, „Француска национална библиотека: историјат, организација, нова библиотека“, Гласник нароgне библиошеке СрSuje 1 (1999): 351-352

${ }^{48}$ E. Stewart Saunders, "Politics and Scholarship in Seventeenth-Century France: The Library of Nicolas Fouquet and the College Royal“, Libraries Research Publications, Paper 17 (1985), preuzeto 12. 12. 2018, https://docs.lib.purdue.edu/lib_research/17/. 
библиотека. ${ }^{49}$ Друга значајна приватна библиотека овога периода припадала је Николасу Фукоу (Nicolas Fouquet, 1615-1680)50 у којој су коришћени Нодеови принципи набавке публикација успостављени у Мазареновој библиотеци. Године 1661, када је, по наредби краља Луја XIV (владао од 1643. до 1715), ухапшен њен власник, имала је 27.000 примерака публикациja, од чега су 1050 били рукописи. Неколико година након његове смрти библиотека је распарчана и њени делови се налазе на различитим местима у Француској и иностранству. Део фонда завршио је у данашњој Француској националној библиотеци. ${ }^{51}$ Од високих званичника Француске за време владавине Луја XIV, велику библиотеку имао је и Жан-Батист Колбер, који је током овог периода бринуо и о Краљевској библиотеци. ${ }^{52}$

У Енглеској је, до времена када је на престо ступио краљ Хенри VIII (владао од 1509. до 1547), који је поседовао најзначајнију владарску библиотеку у 16. веку, сваки црквењак, универзитетски професор и образовани племић имао неку врсту мале колекције књига која је истовремено представљала степен образовања и била знак друштвеног престижа. ${ }^{53}$

Током владавине Хенрија VIII, краљевска библиотека је проширена толико да је обухватала 2500 примерака књига, које су се налазиле у добро опремљеним просторијама палата у Ричмонду, Гриничу, Хемптону и Вестминстеру и њима је руководио обучени библиотекар. Најранији познати инвентар енглеске краљевске библиотеке настао је 1535. у библиотеци ричмондске палате, док вестминстерски представља најбољи извор за увид у њену историју и настао је седам година касније. ${ }^{54}$ Заједно са ширењем колекције, повећаване су и одговорности библиотекара чије дужности су биле да води рачуна о куповини, пописује публикације и организује простор библиотеке. Набавка публикација вршена је на неколико начина: наслеђем од претходних владара, поклонима пријатеља или учењака који су желели да им краљ буде мецена. Поред књига, њен фонд обухватао је мапе, као и планове за спољашње и унутрашње уређење палата, што је имало утицај и на сређивање просторија за библиотеку. ${ }^{55}$

Посебну вредност библиотеке краља Хенрија VIII представљале су књиге које су у њу пристигле на основу Одлуке о распуштању манастира, која је спроведена од 1536. до 1540. године. Наиме, пре ње је на територији Енглеске постојало више од 800 манастира и религијских објеката, а по завршетку ове акције није опстао ниједан. Према речима савременика, скоро сваки од њих имао је библиотеку, а сачувано је само неколико које су биле у оквиру објеката који су припадали катедралама. Највећи део имовине манастирских библиотека завршио је у краљевским палатама Вестминстера и Хемптона. ${ }^{56}$

\footnotetext{
49 Габријел Ноде, француски лекар и библиотекар, сматран је једним од најученијих људи свога доба. Завршио је медицину на универзитетима у Паризу и Падови, али његова прва љубав биле су књиге и библиотеке. Године 1629. позван је у Рим да као библиотекар ради за кардинале Бањија и Барберинија, одакле га кардинал Ришеље позива у Париз да руководи његовом библиотеком. Такође, додељује му почасну титулу лекара краља Луја XIII. Ноде постаје библиотекар кардинала Мазарена 1643, када овај наслеђује Ришељеа на месту премијера Француске. За библиотеку Мазарену, која је сматрана најбољом библиотеком свога доба, сакупио је око 40.000 књига широм Европе. Адаптирајући већ постојећи каталог, Ноде је класификовао књиге према струкама: теологија, медицина, право, филозофија, математика и хуманистичке науке са одговарајућим потподелама. Библиотека је била јавна, а расута је за време Фондеове побуне (1648-1653), када је и Ноде избегао у Шведску. Његово дело Advis pour dresser une bibliothèque (1627), прва је значајна студија из области библиотекарства у модерној Европи. - Детаљније видети у: Encyclopaedia Britannica s.v. "Gabriel Naude, french librarian", preuzeto 8. 1. 2019, https://www.britannica. com/biography/Gabriel-Naude.

50 Министар финансија за време владавине Луја XIV.

51 Saunders, "Politics and Scholarship in Seventeenth-Century France: The Library of Nicolas Fouquet and the College Royal".

52 Stipčević, Povijest knjige, 429.

${ }^{53}$ C. M. Wing, "'Many goodly pleasaunt bokes': The royal library of Henry VIII" (Master of Library and information sci., The Faculty of the School of Library and Information Science San Jose State University, 2002), 20, preuzeto 27. 10. 2021, https://scholarworks.sjsu.edu/etd_theses/2342.

54 Ibid., 32; 34-35.

55 Ibid., 39; 58; 64; 81.

56 Ibid., 133; 137; 142.
} 
Библиотека Бодлеана универзитета Оксфорд је за јавност отворена 1602. Име је добила по Томасу Бодлију (Thomas Bodley, 1545-1613) који јој је завештао личну колекцију књига ${ }^{57}$ и представља основу њеног књижног фонда. Специфичност ове библиотеке огледа се и у томе што су њени каталози били једини који су штампани у Енглеској до 1640, а први је објављен $1605 .^{58}$ Обавезан примерак уведен је у Библиотеку 1610 . године. ${ }^{59}$

На подручју Аустрије, велике краљевске библиотеке постојале су још у средњем веку, али се оснивачем библиотеке династије Хабзбург сматра цар Фердинанд I (владао од 1531. до 1556). Каталоге Библиотеке израдио је крајем 16. века Хуго Блотиус (Hugo Blotius, 1533-1608), ${ }^{60}$ кога је 1576. на то место поставио цар Максимилијан II (владао од 1564. до 1576). ${ }^{61}$

Заслугом архитекте Хуана де Еpepe (Juan de Herrera, 1530-1597), ${ }^{62}$ а уз подршку шпанског краља Фелипеа II (владао од 1556. до 1598), израђена је у оквиру дворца Ескоријал једна од најлепших барокних просторија за библиотеку. ${ }^{63}$ У потрази за сакралним вредностима, људи у краљевој служби трагали су и за рукописима и ретким књигама, јер је Дворска библиотека сматрана и „музејем хришћанства“. Поред тога, краљ је спровео и преглед фондова у свим црквама и манастирима Шпаније ради стварања фонда Библиотеке, а поједине књиге држао је у простору за реликвије, што је још један од доказа колику су вредност оне имала за њега. ${ }^{64}$

Организација фондова библиотека у различитим европским државама бивала је све чешће поверавана научницима, који су, осим правила неопходних за сналажење у оквиру колекција, прописивали и она о изгледу библиотеке, што је значајно допринело побољшању њиховог статуса као културних и образовних установа.

Током раног 17. века настале су две публикације које су се бавиле организацијом библиотеке. Прва, уйушисивво за уређење библиотееке, настала је 1627. и дело је Габријел Нодеа, и другу

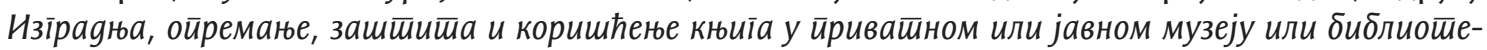
uи... ${ }^{65}$ написао је 1635. Клод Клементе (Claude Clement, 1596-1653). Клементе је писао о значају архитектуре у организацији библиотеке, док главни део Нодеове публикације представља водич за стварање и одржавање књижних колекција које ће користити што више људи. ${ }^{66}$

У свом делу Ноде је пажњу посвећивао организацији и доступности фондова, стварању стручног и алфабетског каталога, времену које би било одређено у току дана да би корисници могли да позајмљују публикације, што би библиотеку чинило приступачном. Сматрао је и да романи, као ни „лака“ поезија немају књижевну вредност, па их је, заједно са литературом која је у његово доба била оспоравана, односно није садржала корисне информације, искључио из фонда. У погледу организације стручног каталога, ослањао се на поделу универзитетске библиотеке у Падови, која је обухватала следеће групе: теологију,

\footnotetext{
57 Stipčević, Povijest knjige, 432.

58 Jane Sears, Library Catalogue of the English Renaissance (Los Angeles: Univeristy of California Press, 1956 ), 38.

59 Ned Irwin, "The Bodleian Library of the University of Oxford", College and Research libraries Vol. 51 No. 2 (March 1990): 100, preuzeto 26. 10. 2021, https://crl.acrl.org/index.php/crl/article/view/14534/15980.

60 Stipčević, Povijest knjige, 423.

61 Детаљније видети у: Paola Molino, "Il mestiere dei libri nel tardo Rinascimento. Edizione e commento del Consilium di Hugo Blotius a Rodolfo II del 1579", 23-24, preuzeto 27. 6. 2020, https://bibliothecae.unibo.it/article/viewFile/5697/5417.

62 Детаљније видети у: Encyclopaedia Britannica S.v. "Juan de Herrera, Spanish architect", preuzeto 8. 1. 2019, https://www.britannica.com/biography/Juan-de-Herrera.

${ }^{63}$ Stipčević, Povijest knjige, 434.

${ }^{64}$ Guy Lazure, "Possessing of the Sacred: Monarchy and Identity in Philip II's Relic Collection at the Escorial", Renaissance Quarterly Vol. 60, No. 1 (Spring 2007): 72-73, preuzeto 24. 1. 2019, https://scholar.uwindsor.ca/cgi/viewcontent. cgi?article $=1008 \&$ context $=$ historypub.

${ }^{65}$ Дигитализована верзија доступна је на: Universitäts-bibliothek Heidelberg, Heidelberg historic literature - digitized, Clément Claude, Mvsei sive bibliothecae tam priuatae quam publicae extructio, instructio, cura, vsus: libri IV, preuzeto 13. 1. 2019, https://digi. ub.uni-heidelberg.de/diglit/clement1635.

${ }_{66}$ Mathilde V. Rovelstad, "Two Seventeenth-Century Library Handbooks, Two Different Library Theories", Libraries \& Culture Vol. 15, No. 4 (Fall 2000): 540, preuzeto 14. 5. 2018, https://www.jstor.org/stable/25548871?seq=1\#page_scan_tab_contents.
} 
медицину, право, историју, филозофију, математику и друштвене науке. С друге стране, Клод Клементе је, при писању свога упутства, био инспирисан колекцијама и декорацијом библиотеке дворца Ескоријал. Он је сматрао да је основна сврха библиотеке размена идеја и књига између образоване елите која је била способна за читање и оцену текстова на грчком и латинском. ${ }^{67}$

Изградња зграде или појединачних просторија за библиотеку такође је служила за бољи смештај публикација и лакше претраживање фондова. Наиме, архитектура библиотека 16. и 17. века временски се поклапала са уметничким правцима периода ренесансе (од 14. до 17. века) и барока (од почетка 17. до краја 18. века). ${ }^{68}$ Најзначајније дело које се бавило ар-

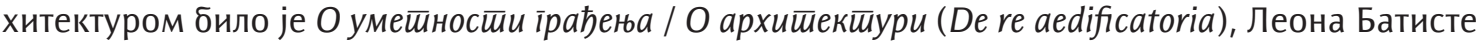
Албертија (Leone Battista Alberti, 1404-1472), објављено 1485. Током 16. века преведено је са латинског на неколико народних језика. Аутор је истицао да библиотека треба да, уколико се налази у сеоској кући, буде у близини власника, док у градској мора да гледа на исток, јер се тамо налази највише светла. ${ }^{69}$ Године 1570. Андреа Паладио (Andrea Palladio,

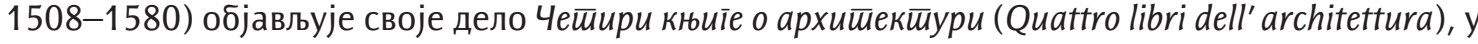
којој даје извесна правила са пропорцијама различитих делова зграде која су се могла применити на било коју библиотеку у класичном и паладијанском стилу 17. века. ${ }^{70}$ У оквиру библиотека овог периода важан део чиниле су и галерије, које су додаване приликом изградње или касније, јер се претпостављало да ће доћи до повећања књижног фонда, па је њихово коришћење било практичније од грађења полица на зидовима и приступа са мердевинама, што је раније био случај. Изградња галерија била је скупља, али знатно сигурнија приликом употребе. ${ }^{71}$ Од декорација су, са почетком модерног доба, најчешће били заступљени портрети на фрескама или платну на којима су представљени познати људи, свеци или учењаци, међу којима су најзначајнији били они повезани са библиотеком или сродним установама. Са другачијом визијом библиотека у овом периоду полако се превазилази и концепт везивања књига ланцима (лат. libri catenati). ${ }^{72}$ Барокна библиотека у оквиру дворова и принчевских резиденција била је визуелна представа моћи и богатства њених власника, као и положаја који су заузимали у друштвеној хијерархији и представљала је наследно богатство. У манастирских библиотекама тога доба барокна иконографија је служила, сагласно учењу Католичке цркве објављеном на сабору у Тренту (1545-1563), ${ }^{73}$ представи Бога, односно моћи коју је имала Црква. ${ }^{74}$ Промена унутар библиотека у освит просветитељског доба може се посматрати и кроз чињеница да је током 17. века и библиотекар војводске библиотеке Брунсвик - Линеберг у Хановеру, а касније и оне херцога Августа у Волфенбителу, Готфрид Вилхелм Лајбниц (Gottfried Wilhelm Leibniz, 1646-1716), закључио да се вредност фонда библиотеке одређује према њеном садржају и коришћењу, а не на основу броја публикација или реткости књиге. ${ }^{75}$

\footnotetext{
${ }^{67}$ Grant, "Two views on the Increasing importance of library access in the Seventeenth Century: Gabriel Naude and Claude Clement": 3-5.

68 Ibid., 541.

${ }^{69}$ P. S. Morrish, "John Willis Clark Revisited: aspects of early modern library design", Library History Vol. 3, Issue 3 (1974): 89, preuzeto 20. 10. 2018, https://www.tandfonline.com/doi/abs/10.1179/lib.1974.3.3.87.

70 Нпр. просторија у којој се налази библиотека требала би да буде окренута ка истоку јер је јутро најподесније време за њено коришћење. - Morrish, "John Willis Clark Revisited: aspects of early modern library design": 90.

71 Ibid.: $96-97$.

72 Ibid.: 103-105.

73 Сабор у Тренту или Тридентски концил донео је низ одлука које су имале за циљ јачање папског централизма и очување средњовековних верских догми, као и борбу против реформације и напредних филозофских и научних схватања. - Детаљније видети у: Мала енциклойеgија йросвейа: ойшйа енциклойеgија. 2. М-Ш, 2. изд. (Београд: Просвета, 1970), 724.

74 Rovelstad, "Two Seventeenth-Century Library Handbooks, Two Different Library Theories", 543.

75 Alberto Mangel, Biblioteka noću (Beograd: Geopoetika, 2008), 85-86.
} 


\section{Закључак}

Током 16. века штампана књига не само да је добила равноправни статус са рукописном, која је у Европи негована од раног средњег века, него је, и у животу савременика и у фондовима библиотека, изборила апсолутни примат. Била је то последица не само бржег умножавања, него и развоја науке и технике који је довео до специјализације знања и наглог увећања обима података из различитих научних и стручних области. Но, била је то и последица укупне демократизације образовања и информисања, која ће у наредним вековима довести до важних друштвених реформи.

Са штампаном књигом убрзано су почели да расту фондови библиотека, а умножили су се и типови публикација које се у библиотекама налазе. Рукописна књига постаје један од раритетних фондова библиотека, а у библиотечке збирке полако улазе новине, часописи, плакати, леци, други штампани материјал попут музикалија те гравире и медаље. Обим и разноликост грађе нужно су водили потреби ефикасног уређивања, па су се и краљевске и универзитетске и специјалне библиотеке нашле пред императивом израде ауторских и стручних каталога. Но, каталошка пракса у библиотекама остала је врло разнолика. Први теоријски радови из области уређења библиотека показују колико је та проблематика била важна за савременике који све чешће истичу потребу за већом доступношћу публикација. Ти радови доприносили су повећању знања о могућим начинима организације фондова и интернационализацији ове проблематике, што је, током следећих стотинак година, довело до стварања савремених типова библиотека. Иза свих ових напора, заправо, лагано су почеле да се назиру контуре корисника као централне личности комуникационог ланца у библиотечкој делатности.

\section{Литература и извори:}

1. Borstin, Danijel Dž. Svet otkrića: Pripovest o čovekovoj potrazi za spoznajom sveta i samog sebe. Beograd: Geopoetika, 2003.

2. Duroselle-Melish, Caroline and David A. Lines. "The Library of Ulisse Aldrovandi (+1605): Acquiring and Organizing Books in Sixteenth Century Bologna". The Library $7^{\text {th }}$ series, Vol. 16, No. 2 (June 2015): 133-161. Preuzeto 16. 11. 2017. https://s3.amazonaws.com/academia.edu.documents/38146759/ Library-2015-Duroselle-Melish-Lines-final.pdf?AWSAccessKeyId=AKIAIWOWYYGZ2Y53UL3A\&Expires $=1510856027 \&$ Signature $=$ C\%2BB\%2F5cPXTvYlwlQKXSvshsLeYDo\%3D\&response-content-disposition=inline\%3B\%20filename\%3DThe_Library_of_Ulisse_Aldrovandi_1605_Ac.pdf.

3. Encyclopaedia Britannica. Preuzeto 8. 1. 2019. https://www.britannica.com/.

4. Encyclopedia of Library History. Ed. Wayne A. Wiegand and Donald Davis. New York: Garland Publishing, 1994.

5. Grant, Erin M. "Two views on the Increasing importance of library access in the Seventeenth Century: Gabriel Naude and Claude Clement". Georgia Library Quarterly Vol. 50, Issue 4, Article 10 (Fall 2013): 1-6. Preuzeto 15. 11. 2018. http://digitalcommons.kennesaw/glq/vol50/iss4/10.

6. Injac, Vesna. „Francuska nacionalna biblioteka: istorijat, organizacija, nova biblioteka“. Glasnik narodne biblioteke Srbije 1 (1999): 351-352.

7. Irwin, Ned. "The Bodleian Library of the University of Oxford". College and Research libraries Vol. 51 No. 2 (March 1990): 100-106. Preuzeto 26. 10. 2021. https://crl.acrl.org/index.php/crl/article/ view/14534/15980.

8. Keningsberg, Helmut G., Džeri K. Bouler i Džeri L. Mouz. Evropa u šesnaestom veku. Beograd: Clio, 2002.

9. Komelja, Beatris. Španska inkvizicija. Beograd: Clio, 2003. 
10. Lazure, Guy. "Possessing of the Sacred: Monarchy and Identity in Philip II's Relic Collection at he Escorial“. Renaissance Quarterly Vol. 60, No. 1 (Spring 2007): 58-93. Preuzeto 24. 1. 2019. https://scholar.uwindsor.ca/cgi/viewcontent.cgi?article=1008\&context=historypub.

11. Mala enciklopedija prosveta: opšta enciklopedija. 2. M-Š, 2. izd. Beograd: Prosveta, 1970.

12. Mangel, Alberto. Biblioteka noću. Beograd: Geopoetika, 2008.

13. Molino, Paola. "Il mestiere dei libri nel tardo Rinascimento. Edizione e commento del Consilium di Hugo Blotius a Rodolfo II del 1579", 23-77. Preuzeto 27. 6. 2020. https://bibliothecae.unibo.it/article/ viewFile/5697/5417.

14. Morrish, P. S. "John Willis Clark Revisited: aspects of early modern library design". Library History Vol. 3, Issue 3 (1974): 87-107. Preuzeto 20. 10. 2018. https://www.tandfonline.com/doi/abs/10.1179/ lib.1974.3.3.87.

15. Museum Plantin Moretus. Preuzeto 17. 10. 2021. https://www.museumplantinmoretus.be/en.

16. Nuovo, Angela. Gian Vincenzo Pinelli's collection of catalogues of private libraries in sixteenth century Europe, 129-144. Preuzeto 20. 10. 2018. https://www.academia.edu/3868798/

Gian_Vincenzo_Pinellis_collection_of_catalogues_of_private_libraries_in_sixteenth-century_Europe.

17. Nuovo, Angela. The Creation and Dispersal of the Library of Gian Vincenzo Pinelli, 39-67. Preuzeto 19. 10. 2018. http://www.academia.edu/3870620/ The_Creation_and_Dispersal_of_the_Library_of_Gian_Vincenzo_Pinell.

18. Oliver, Bette W. "The Bibliotheque nationale from 1792 to 1794: Becoming a National Institution during the French Revolution“. Libraries \& Cultural Record Vol. 42, No. 1 (2007): 48-56. Preuzeto 17. 5. 2017. https://www.jstor.org/stable/25549380?seq=1\#page_scan_tab_contents.

19. Pelc, Milan. Pismo - knjiga - slika: Uvod u povijest informacijske kulture. Zagreb: Golden marketing, 2002.

20. Peri, Marvin. Intelektualna istorija Evrope. Beograd: Clio, 2002.

21. Pet vekova srpskog štamparstva 1494-1994: razdoblje srpskosloveske štampe: XV-XVII v. Prir. Mitar Pešikan, Katarina Mano-Zisi i Miljko Kovačević. Beograd: Srpska akademija nauka i umetnosti; Naroda biblioteka Srbije; Novi Sad: Matica srpska, 1994.

22. Rovelstad, Mathilde V. "Two Seventeenth-Century Library Handbooks, Two Different Library Theories". Libraries \& Culture Vol. 15, No. 4 (Fall 2000): 540-556. Preuzeto 14. 5. 2018. https://www.jstor.org/ stable/25548871?seq=1\#page_scan_tab_contents.

23. Sears, Jayne. Library Catalogue of the English Renaissance. Los Angeles: Univeristy of California Press, 1956.

24. Stipčević, Aleksandar. Povijest knjige. Zagreb: Izdavački zavod Matice hrvatske, 1985.

25. Stipčević, Aleksandar. Povijest knjige: drugo, prošireno i dopunjeno izdanje. Zagreb: Matica hrvatska, 2006.

26. Saunders, Stewart E. "Politics and Scholarship in Seventeenth-Century France: The Library of Nicolas Fouquet and the College Royal“. Libraries Research Publications, Paper 17 (1985). Preuzeto 12. 12. 2018. https://docs.lib.purdue.edu/lib_research/17/.

27. Universitäts-bibliothek Heidelberg, Heidelberg historic literature - digitized, Clément, Claude. Mvsei sive bibliothecae tam priuatae quam publicae extructio, instructio, cura, vsus: libri IV. Preuzeto 13. 1. 2019. https://digi.ub.uni-heidelberg.de/diglit/clement1635.

28. Wing, C. M. ",Many goodly pleasaunt bokes': The royal library of Henry VIII". Master of Library and information sci., The Faculty of the School of Library and Information Science San Jose State University, 2002. Preuzeto 27. 10. 2021. https://scholarworks.sjsu.edu/etd_theses/2342. 


\title{
Libraries, Printing and Publishing in Europe in the $16^{\text {th }}$ and $17^{\text {th }}$ Centuries
}

\begin{abstract}
Summary
This paper presents the most important changes in the field of "book" publishing and printing that occurred in the $16^{\text {th }}$ and $17^{\text {th }}$ centuries. Publishing and printing are presented through an overview of the activities of notable individuals and groups in different European countries, with a parallel overview of some new media: leaflets, pamphlets, brochures, and periodicals such as calendars, almanacs, newspapers, and magazines.

In the paper, the political, religious, and cultural changes brought by the strengthening of the absolutism of the rulers, Protestantism, the Reformation, the scientific revolution, and Baroque as a style in art, are observed from the positions of both book historians and library historians. The decline of monastic collections of books, which throughout the Middle Ages were the most important custodians of written heritage, the development of royal collections, university and special libraries, private libraries of wealthy citizens, funds organization, the status of librarians, and library architecture, are presented in such a way as to testify clearly to the social foundation of library activities. The importance of texts on the arrangement of libraries that appeared in the first half of the $17^{\text {th }}$ century is especially underlined. They show how important this issue was for the contemporaries who increasingly emphasized the need for greater availability of publications. These works contributed to the increase of knowledge about possible ways of organizing funds and the internationalization of this issue, which, over the next hundred years, led to the creation of the modern types of libraries. Behind all these efforts, the contours of a user as the central figure of the communication chain in the library activity slowly began to be discerned.
\end{abstract}

Keywords: Europe, $16^{\text {th }}$ and $17^{\text {th }}$ centuries, librarianship, libraries, organization, architecture, publishing, printing, books, periodicals 